\title{
Narcissism and Aggression in Counselor Candidates: A Challenge for Counselor Education in Indonesia
}

\author{
Budi Purwoko, Fifi Khoirul Fitriyah
}

The State University of Surabaya, East Java, Indonesia

\begin{abstract}
Counselor is one of the major components for successful learning in school, therefore it is important to avoid either narcissistic or aggression inside counselor personality. The purpose of this study is to explore the phenomena and to test the relations. The subjects were counselor candidate in university aged 20-22 years old $(M=20,73)$. The result shows that 43 of 169 prospective counselor in university executed narcissistic personality disorder (NPD), then it correlated with aggression ( $r$ $=0.673$ ). Cognition factor is very influential in the development of NPD. This is a serious problem in counselor education's sphere, further research needs to prepare appropriate intervention for reducing either narcissistic or aggression in counselor education.
\end{abstract}

Keywords: $\quad$ Aggression, Counselor, Education, and Narcissistic

\section{INTRODUCTION}

In Indonesia, counselor has important role to help students in school. According to Dollarhide and Saginak (2012), professional school counselors educate students in new ways of dealing with relationships with self, others, and the world. Therefore, counselor is prosecuted to be perfect. In truth, counselor is also a human being who has different needs and different fulfillment ways.

For some people, narcissistic behavior is necessary to survive but in negative way (Maata, et al., 2012). Even narcissistic is common in humans in early adulthood (DSM-IV 1994). Early adulthood is an important period between 18-40 years (Hurlock 1999). In the study, counselor candidates are university student included in the early adult developmental period. Previous research shows increasing trend in narcissistic among university students in America (Twenge \& Joshua 2010).

Narcissistic has unfavorable impact on social and emotional relationships, since narcissistic individuals tend to be inflexible in self-improvement (Campbell et al. 2000) and unrealistic in careers (Carr 2008). Narcissistic individual has very little capacity for empathy either cognitive or emotion with others (Kernberg 2004, Ritter et al., 2010). In the other hand, empathy is very important which is must be had by counselor.

Previous studies show positive correlation between narcissistic and aggression (Thomaes, et al. 2009; Ongen 2010; Lambe, et al., 2016). Therefore, aggression also must be studied. International Center for Research on Women (ICRW) shows 84\% students show aggression in Indonesia. In this case, Indonesia is higher than Vietnam (79\%), Nepal (79\%), Cambodia (73\%), and Pakistan (43\%) (National.republika.co.id, February 22, 2017), 259,150 cases Are aggression in women during 2016
(Kompas.com, March 7, 2017). Aggression is very harmful for human life (Buss 1961).

Aggression is not just the visible behavior. According Buss (1961), aggression is divided in four aspects; Physic, verbal, anger, and hostility. Physical aggression is an attack behavior that causes physical injury, whereas verbal aggression is an attacking behavior using words to threaten or rejection causing psychic injury. Unlike the two previous aspects, anger is an emotional response that drives aggressive behavior. Whereas hostility is a restrained mind response that includes evil intent and negative evaluation about others.

Either narcissistic or aggression is not well owned by a counselor candidate. Prospective counselors are required to have good personality competencies, in addition to the pedagogical, social, and professional competencies (Ministry of National Education Regulation 2008).

In the study, counselor candidates are students of guidance and counseling courses or future counselors. The study aimed (1) to discover the phenomena of narcissistic and aggression in counselor candidates, and (2) to find the correlations between narcissism and aggression problems in counselor candidates. About counselor profession competencies will be discussed in this paper.

\section{METHOD}

This study was conducted in Department of Guidance and Counseling, Faculty of Educational Studies, The State University of Surabaya, East Java, Indonesia. A sample was 223 counselor candidates aged 18-22 years $(M=21,33)$.

This study utilized two types of scale. First, Narcissistic Personality Inventory (NPI) which was developed by Raskin and Hall in 1979 (Raskin \& Terry 1988). But this study used NPI in the newest 
version, NPI-16 which was adapted by Ames, et al. (Ames, et al. 2005). Second, Buss and Perry Aggression Questionnaire (BPAQ) which was developed by Buss A.H. and Perry M. in 1992. The aspects were physical aggression, verbal aggression, anger, and hostility, related to Buss's book "The Psychology of Aggression" in 1961. Previous study found BPAQ was proved valid and reliable to measure aggression (Gerevinch, et al. 2007), then also in Argentina's version (Reyna, et al. 2011) and Turki's version (Demitras-Madran 2013).

Both of the scales were adapted in Indonesia version. Either NPI-16 (16 items, $\alpha=0.91)$ or BPAQ (29 items, $\alpha=0.88$ ) were proved valid and reliable. Data analyzes used descriptive statistic for the first question and Pearson Correlation for the second question.

\section{RESULT}

\subsection{Narcissistic Phenomena Candidate

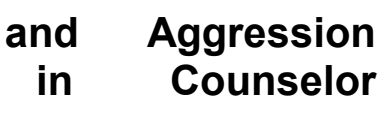

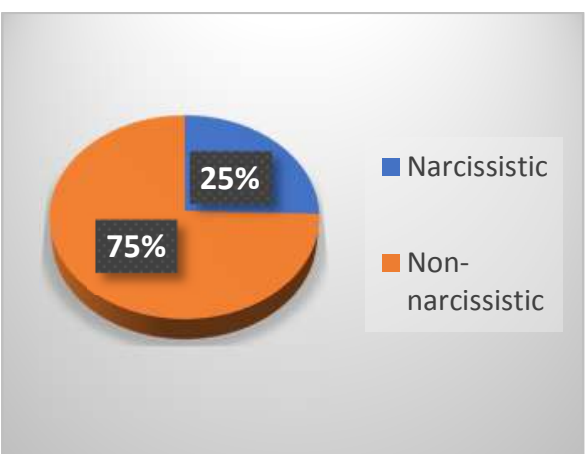

Figure 1. The proportion of narcissistic individual in counselor candidate in The State University of Surabaya

The data were gathered from questionnaire of NPI-16 and BPAQ which was filled by 223 university students or counselor candidate in The State University of Surabaya.

By using NPI-16 questionnaire, figure 1 shows $25 \%$ (43) of counselor candidate in The State University of Surabaya were narcissistic. In the other hand, 75\% (126) others were non-narcissistic.

Figure 2. The proportion of aggression level in counselor candidate in The State University of Surabaya

By using BPAQ, figure 2 shows 17\% (29) of counselor candidate was in high aggression level and $10 \%$ (77) of it was in low aggression level. This proportion was calculated by $\mathrm{Z}$ score.

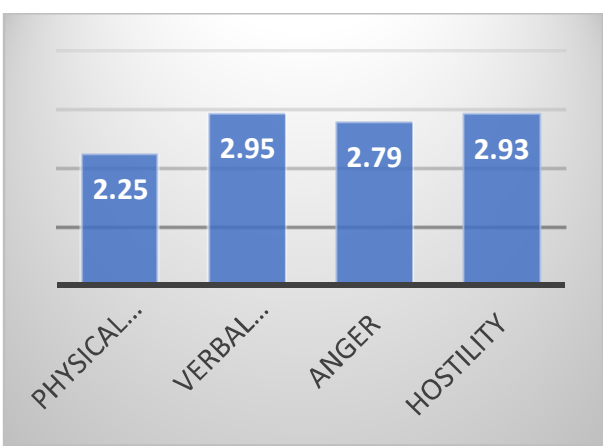

Figure 2. The proportion of aggression aspects in counselor candidate in The State University of Surabaya

Figure 3 shows the average of aggression aspects score in counselor candidate in The State University of Surabaya. By using scale 1-5, verbal aggression and hostility were the highest average score $(2,95$ and $2,93)$, whereas physical aggression was the lowest average score $(2,25)$. Anger was in the medium position $(2,79)$.

\subsection{The Link between Narcissistic and Aggression in Counselor Candidate}

In this correlation described about the relation between narcissistic and aggression, then between narcissistic and aggression aspects (physical aggression, verbal aggression, anger, and hostility). So, it can be known which aspects were most strongly related to narcissistic. The data analysis used Pearson Correlation, then it was analyzed by using SPSS 20.

Table 1. Pearson Correlation analysis between narcissistic and aggression

\begin{tabular}{|c|c|c|c|}
\hline \multirow{5}{*}{ Narcissistic } & & Narcissistic & Aggression \\
\hline & $\begin{array}{c}\text { Pearson } \\
\text { Correlation }\end{array}$ & 1 &, $673^{* *}$ \\
\hline & $\begin{array}{l}\text { Sig. (2- } \\
\text { tailed) }\end{array}$ & &, 000 \\
\hline & $\mathrm{N}$ & 169 & 169 \\
\hline & $\begin{array}{l}\text { Pearson } \\
\text { Correlation }\end{array}$ &, $673^{* *}$ & 1 \\
\hline \multirow[t]{2}{*}{ Aggression } & $\begin{array}{l}\text { Sig. (2- } \\
\text { tailed) }\end{array}$ & ,000 & \\
\hline & $\mathrm{N}$ & 169 & 169 \\
\hline **. Corre & $\begin{array}{r}\text { tion is signific } \\
\text { taile }\end{array}$ & $\begin{array}{l}\text { ant at the } 0 \text {. } \\
\text { d). }\end{array}$ & level (2- \\
\hline
\end{tabular}

The table 1 above shows the correlation between narcissistic and aggression in counselor candidate. By using data analysis of Pearson Correlation, it was proved positive and strong correlation $(\mathrm{r}=0.673)$. Further, table 2 will be showed Pearson Correlation analysis between aggression aspects. 
Table 2. Pearson Correlation analysis between narcissistic and aggression's aspects

\begin{tabular}{ccc}
\hline & & Narcissistic \\
Physical_ & Pearson Correlation &, $527^{* *}$ \\
Agg & Sig. (2-tailed) &, 000 \\
& N & 169 \\
Verbal_A & Pearson Correlation &, $387^{* *}$ \\
gg & Sig. (2-tailed) &, 000 \\
& N & 169 \\
Anger & Pearson Correlation &, $495^{* *}$ \\
& Sig. (2-tailed) &, 000 \\
& N & 169 \\
Hostility & Pearson Correlation &, $558^{* *}$ \\
& Sig. (2-tailed) &, 000 \\
& N & 169 \\
\hline$* *$ Correlation is significant at the 0.01 \\
\multicolumn{3}{c}{ level (2-tailed). }
\end{tabular}

Table 2 depicts Pearson Correlation result between narcissistic and aggression aspects using SPSS 20. In general, narcissistic had positive and strong correlation with all aspects of aggression but it had different correlation coefficient.

The strongest correlation was between narcissistic and hostility $(\mathrm{r}=0.558)$, then physical aggression $(0.527)$. In the other hand, the lowest correlation was between narcissistic and verbal aggression (0.387). Then, correlation in the middle position was anger (0.495).

\section{DISCUSSION}

This research is based on previous studies which states that the narcissistic trend in students is increasing (Twenge \& Joshua 2010). Narcissistic phenomena's trend can not be avoided in individuals in this period.

The age of college students generally falls within the initial adult age range. DSM-IV (1994) mentions that this narcissistic behavior is a common disorder in humans especially in early adulthood. Hurlock (1999) states that early adulthood is age with a range between 18 years to 40 years. This early adulthood was an important period in which this period was based (Santrock, 2002), individuals worked harder in relationships with the opposite sex and left little time for anything else. Based on these views it can be concluded that the student is included in the early adult age range which has high potential for narcissistic personality disorder.

The result show $25 \%$ of counselor candidate in The State University of Surabaya is narcissistic. This percentage is high enough to require serious attention. These results are different from previous studies conducted in California. The study using NPI showed the students of psychology counseling study program did not experience narcissistic (Clark 1991).

In fact, narcissistic does not show any disturbing behavior, in fact most of them are able to socialize well (Kernberg 2004). In the other hand, the problem is dangerous much less closely related to aggression.
Narcissistic becomes a more serious problem because it correlates with aggression. The results showed a strong correlation between narcissistic and aggression $(r=0.673)$. These results are in line with previous research that has been done by Thomaes et al. (2009), Ongen (2010), and Lambe et al. (2016).

Aggression is not only visible behavior, the result of this study indicates that the aspect of hostility in aggression has the strongest correlation with narcissistic. This proves the cognitive factor is very instrumental in the emergence of narcissistic personality disorder. In the other hand, hostility aspect in this research is one of the highest average scores. This shows that hostility is the most dominant aggression aspect compared to others.

According to Buss (1961), hostility encompasses negative thoughts about others and malice. Such thoughts may be a manifestation of self-denial of true identity. True Self in this case should be avoided because it is considered inferior, unfeasible, and not in accordance with the projected self-image. In an attempt to gain recognition, a narcissistic individual will mask his inferiority with superior self-image. This self-image then becomes façade that is so strong and visible as identity (Campbell 2000, Lowen in Krajo 2007).

The findings are different from Freud's views. Prior to that, Freud argued that narcissism generally arises in every individual when the libido which is psychic energy is invested in self-satisfaction so that there is an inability to invest it in others or for the benefit of others. The behavior that arises as a result of this narcissistic is seen as excessive self-love (Mollon 2004).

Narcissistic phenomenon in students, especially counselor candidate is important to get serious attention. Narcissistic tends to be closely related to lack of empathy (Kernberg 2004, Ritter et al., 2010) and has a low reality level (Carr 2008). In Indonesia, one of the personality competencies that must be possessed is showing the integrity and stability in strong personality. One aspect is the sensitivity and empathy (Ministry of National Education, 2008), so prospective counselors should avoid narcissistic personality disorder.

Narcissistic individuals will experience difficulties in applying the behavior in accordance with the standards of personality competence of counselors required in the Regulation of the Minister of National Education No. 27 of 2008. On the second and third core competencies in particular, namely; respect and uphold the values of humanity, individuality, and freedom of choice and demonstrate strong integrity and stability of personality. Both of these competencies contradict the narcissistic characteristics mentioned in DSM-IV (1994).

University students in the field of guidance and counseling is in the learning stage of becoming a counselor, so it is important to have a good personality. In the end, they are able to become a 
counselor as required. Therefore, it is important that the handling for narcissistic individuals, especially the students of guidance and counseling study program or counselor candidates. It is expected that when they become school counselors can have a good personality at least in accordance with the provisions of the Ministry of National Education Regulation 2008 Number 27 on the standards of academic qualifications and counselor competence. But still must also have other standard competencies, namely; Pedagogic, social, and professional.

Either narcissistic or aggression in counselor candidates manifests towards future counseling services when they become counselors, so it is necessary to be addressed early on. This is a challenge for counselor education to prepare a curriculum oriented towards the improvement of personality competence.

\section{CONCLUSION}

This study aim is to describe narcissistic and aggression profile in counselor candidate. The results show narcissistic is not only about excessive selflove but an attempt to deny its true identity. This is evidenced by the existence of a very strong relationship between narcissistic and hostility. In one side, hostility is part of the aggression that is formed through negative thinking about events and malicious intentions against others. The cognitive aspect predominantly influences the emergence of narcissistic personalities.

Either narcissistic or aggression on the counselor candidate is important to be reduced. Therefore, it is important to develop good curriculum that supports the development of personality competence of the counselor to avoid narcissistic personality.

Counseling interventions to reduce either narcissistic or aggression at the university level, especially to potential counselors are important to formulate and investigate further. These issues are important to be resolved immediately, requiring effective and efficient interventions.

\section{REFERENCES}

[1] Ames, Daniel R., et al. (2005). The NPI-16 as a short measure of nercissism. Journal of Research in Personality 40 (2006) 440-450, doi: 10.1016/j.jrp.2005.03.002.

[2] Buss, Arnold H. (1961). The Psychology of Aggression. New York and London: John Wiley and Sons, Inc.

[3] Campbell, W. Keith, et al. (2000). Narcissism and Comparative Self-Enhancement Strategies. Journal of Research in Personality 34, 329-347. DOI:10.1006/jrpe.2000.2282.

[4] Carr, Darrin L. (2008). Relationship among overt and covert narcissism and vocational interests with respect to gender. (Dissertation, Florida State University).

[5] Clark, Judith Z. (1991). Therapist Narcissism. Proffessional Psychology, 1991, vol 22, no. 2, 141-143.

[6] Demitras-Madran, Andac. (2013). The reliability and validity of the Buss-Perry Aggression Questionnaire (BPAQ)-Turkish Version. Turkish Journal of Psychiatry 2013 Summer; 24(2):1249.

[7] Diagnostic and Statistical Manual of Mental Disorder, Fourth Edition (DSM-IV). (1994). Washington, DC: American Psychiatric Association.

[8] Gerevinch, J. et al. (2007). The generalizability of the Buss-Perry Aggression Questionnaire. Int J Methods Psychiatr Res 2007; 16(3): 124-136.

[9] Hurlock, Elizabeth B. (1999). Psikologi Perkembangan (Istiwidayanti \& Soedjarwo, Trans.). Jakarta: Erlangga.

[10] Kernberg, Otto F. (2004). Aggressivity, Narcissism, and Self-Destructiveness in the Psychotherapeutic Relationship: New Development in the Psychopathology and Psychotherapy of Severe Personality Disorder. New Haven and London: Yale University Press.

[11] Krajo, Kathy. (2007). What makes narcissists tick. USA, www.OperationDoubes.com.

[12] Lambe, Sinead., et al. (2016). The role of narcissism in aggression and violence: A systemic review. Trauma, Violence, \& Abuse, doi:10.1177/1524838016650190.

[13] Maatta, Marju., et al. (2012). An intimate relationship in the shadow of narcissism: What is it like to live with narcissistic spouse? International Journal of Research Studies in Psychology, Volume 1 Number 1, 37-50.

[14] Ministry of National Education Regulation. 2008. Number 27 about Academic Qualifications and Counselor Competence.

[15] Mollon, Phil. (2004). The fragile self: The structure of narcissistic disturbance. London: Whurr Publishers Ltd.

[16] Ongen, Demet Erol. (2010). Relationship between narcissism and aggression among nonreferred Turkish university students. Social and Behavioral Sciences, Volume 5, 2010, Pages 410-415.

[17] Raskin, R., and Terry, H. (1988). A principalcomponents analysis of the Narcissistic Personality Inventory and further evidence of its construct-validity. Journal of Personality and Social Psychology, Vol 54(5), 890-902.

[18] Reyna, Cicilia., et al. (2011). The Buss-Perry Aggression Questionnaire: Construct validity and gender invariance among Argentinean adolescents. International Journal of Psychological Research, 4 (2), 30-37. 
[19] Ritter, Kathrin., et al. (2010). Lack of empathy in patiens with narcissistic personality disorder. Psychiatry Research, PSY-06655.

[20] Santrock, J. W. (2002). Perkembangan Masa Hidup. Jakarta: Erlangga.

[21] Thomaes, Sander., et al. (2009). Reducing narcissistic aggression by buttressing self- esteem: An experimental field study.

Psychological Science, Vol 20, Issue 12, 2009.

[22] Twenge, Jean M., \& Joshua D. Foster. (2010).

Birth cohort increases in narcissistic personality traits among American college students, 19822009. Social Psychological and Personality Science, 1 (1) 99-106. 